\title{
Physiology of Weeds in Intraspecific Competition
}

\author{
Caroline Hernke Thiel ${ }^{1}$, Felipe Adelio de David ${ }^{2}$, Leandro Galon ${ }^{2}$, Sidnei Deuner ${ }^{1}$, Cesar Tiago Forte ${ }^{2}$, \\ Gismael Francisco Perin ${ }^{2}$, Paula Rochelly de David ${ }^{2}$, Altemir José Mossi ${ }^{2}$, André Andres ${ }^{3} \&$ Germani Concenço $^{3}$ \\ ${ }^{1}$ Universidade Federal de Pelotas, Campus Capão do Leão, Pelotas, RS, Brazil \\ ${ }^{2}$ Universidade Federal da Fronteira Sul, Campus Erechim, Erechim, RS, Brazil \\ ${ }^{3}$ Embrapa Clima Temperado, Estação Terras Baixas, Pelotas, RS, Brazil \\ Correspondence: Caroline Hernke Thiel, Departamento de Botânica, Universidade Federal de Pelotas, Caixa \\ Postal 354, 96010-900, Campus Capão do Leão, Pelotas, RS, Brazil. Tel: 53-3275-7344. E-mail: \\ carol_thiel24@hotmail.com
}

$\begin{array}{ll}\text { Received: February 27, } 2018 & \text { Accepted: April 22, } 2018 \quad \text { Online Published: May 15, } 2018 \\ \text { doi:10.5539/jas.v10n6p334 } & \text { URL: https://doi.org/10.5539/jas.v10n6p334 }\end{array}$

\begin{abstract}
When plants are subjected to competition, their physiological behavior changes. To understand the developmental physiology of weeds will subsidize the development of cropping systems which favor the crops plants in detriment of weeds. The objective of this work was to evaluate the physiological behavior of different weed species, growing under intraspecific competition. Greenhouse experiment was conducted in randomized complete block design arranged in factorial scheme $4 \times 5$ with four replications. Factor A was the weed species [Urochloa plantaginea (Alexandrergrass), Bidens pilosa (hairy beggarticks), Ipomoea indivisa (morningglory) and Conyza bonariensis (hairy fleabane)], and factor B was the plant density of these species $(20,40,60,80$ or 100 plants $\mathrm{m}^{-2}$ ). The following variables were evaluated: sub-stomatal $\mathrm{CO}_{2}$ concentration, photosynthesis rate, consumed $\mathrm{CO}_{2}$, stomatal conductance, transpiration rate, water use efficiency, plant height, shoot diameter, leaf area, and shoot dry biomass. Alexandergrass relies on the superior control of stomatal opening and high water use efficiency. Hairy beggarticks efficiency in competition lies on its ability to remove water from soil to levels when the other surrounding plant species would undergo stress. Morning glory and hairy fleabane did not present detectable particular features in the study, and their importance as weeds is probably tied to other survival abilities but superior competition. In conclusion, the weed species studied present distinct competitive strategies.
\end{abstract}

Keywords: Bidens pilosa, Conyza bonariensis, Ipomoea indivisa, Urochloa plantaginea, weed behavior

\section{Introduction}

From an agronomic point of view, plants can be divided into two groups: desired or undesired. However, no specific plant species can be considered a weed, as this will depend on the place and time when this species is present in the field. Even a plant of economic interest, such as corn, can be considered harmful if it is growing within a soybean crop (Concenço, Aspiazu, Ferreira, Galon, \& Silva, 2012).

Plants are sessile organisms, and are subjected to both adverse environmental conditions and competition. Among several interpretations, "competition between plants" essentially results in reduced performance of a particular plant species of importance, due to the shared use of a limited available resource (Gurevitch, Scheiner, \& Fox, 2009). Competition may be interspecific when occurring between different species, and intraspecific when occurring between individuals of the same species (Radosevich, Holt, \& Ghersa, 1997).

When plants are submitted to competition, the physiological characteristics of growth and development are generally altered (Galon et al., 2014). This results in differences in the use of environmental resources, especially water, which directly affects the availability of $\mathrm{CO}_{2}$ in leaf mesophyll and therefore photosynthetic efficiency (Procópio, Santos, Silva, Donagemma, \& Mendonça, 2004b). According to Vasconcelos, Silva, and Lima (2012), the greater the similarity between the competing individuals, the greater will be the losses caused by competition between them, reaching the maximum stress when competition occurs between weeds and crops of the same family, since the species have very similar nutritional requirements. Intraspecific competition, therefore, is more intense because it occurs among morphogenetically identical (or from the same species) individuals (Gurevitch et al., 2009). 
Darwin identified the central role of competition in selection processes of organisms in general. Since then, competition has been regarded as one of the major forces behind the appearance and life history of plants, and the structure and dynamics of plant communities (Bastiaans \& Kropff, 2017). Understanding the physiology of development, for both weed and crop plants, can subsidize the planning of production systems that optimize inhibition of weed growth. According to Sardana, Mahajan, Jabran, and Chauhan (2017), different weed species, in similar plant density, vary in their ability to compete with crops due to inequalities in growth habit and speed, adaptability to local edaphoclimatic conditions and carbon metabolism, among other characteristics. Consequently, the physiological behavior is quite distinct among species.

Urochloa plantagínea (Alexandergrass), Bidens pilosa (hairy beggarticks), Ipomoea indivisa (morningglory) and Conyza bonariensis (hairy fleabane) are considered to be weeds due to characteristics such as high competitive ability, propagation capacity, germination and growth speed, germination and emergence from deep soil layers, and viability under unfavorable conditions (Brighenti \& Oliveira, 2011). However, different weed species have specific physiological characteristics which provides growth advantage in the competition. Alexandergrass, for example, presents $\mathrm{C}_{4}$ metabolism, and consequently greater efficiency of water use compared to several other weeds (Aspiazú et al., 2010a). In another study, hairy beggarticks was very efficient in soil water extraction, rapidly subjecting nearby plant species to water deficit (Procópio et al., 2004b). Hairy fleabane, in turn, is considered a cosmopolitan species that has great adaptability to the environment because it is of recent evolutionary origin, demonstrating distinct physiological responses to different stimuli (G. Concenço \& S. E. Concenço, 2016).

The understanding of the factors intrinsic to the population of a certain species, more specifically the physiology of intraspecific competition, subsidizes the search for solutions to weed management techniques, which are responsible for large qualitative and quantitative losses of agricultural production (Sardana et al., 2017). Once we find the weak point of a given weed species, it will be easier to control it. Therefore, the objective of this work was to evaluate the physiological behavior of different weed species, growing under intraspecific competition.

\section{Material and Methods}

The study was installed into greenhouse, at the Federal University of the Southern Border (UFFS), Campus Erechim, RS, Brazil, from May to December 2015. The experimental design was randomized complete blocks, arranged in $4 \times 5$ factorial scheme, with four replications. Factor A represented the weed species (Urochloa plantaginea-Alexandergrass, Bidens pilosa-hairy beggarticks, Ipomoea indivisa-morningglory and Conyza

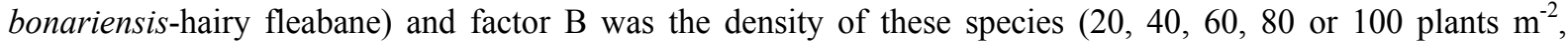
corresponding to 1, 2, 3, 4 or 5 plants per pot). Experimental plots consisted of plastic pots with $12 \mathrm{~L}$ of soil.

The soil was chemically characterized as follows: $\mathrm{pH}_{\text {(water) }} 5.2$, organic matter $2 \%, \mathrm{P} 6.4 \mathrm{mg} \mathrm{dm}^{-3}$, and Ca, $\mathrm{Mg}^{-3}$ and $\mathrm{CTC}_{(\mathrm{pH} 7.0)}$ were $12,3.8$ and $21.8 \mathrm{cmol}_{\mathrm{c}} \mathrm{dm}^{-3}$, respectively.

The weeds were planted in the first half of August. Irrigations were performed according to the demand, aiming to keep soil moisture approximately at the field capacity (about 10 to $20 \mathrm{kPa}$ of water tension for the soil used in this study).

Seventy days after planting (DAP), at the early reproductive phase, the sub-stomatal $\mathrm{CO}_{2}$ concentration $(\mathrm{C} i$ - $\mu$ mol $\left.\mathrm{mol}^{-1}\right)$, photosynthetic rate $\left(A-\mu \mathrm{mol} \mathrm{m} \mathrm{m}^{-1}\right), \mathrm{CO}_{2}$ consumed $\left(\Delta C-\mu \mathrm{mol} \mathrm{mol}{ }^{-1}\right)$, stomatal conductance $\left(G s-\mathrm{mol} \mathrm{m}^{-2}\right.$ $\left.\mathrm{s}^{-1}\right)$, transpiration rate $\left(E-\mathrm{mmol} \mathrm{H}_{2} \mathrm{O} \mathrm{m}^{-2} \mathrm{~s}^{-1}\right)$ and water use efficiency (WUE- $\mu$ mol $\mathrm{CO}_{2} \mathrm{~mol} \mathrm{H}_{2} \mathrm{O}^{-1}$ ) were assessed at the middle third of the first fully expanded leaf of each weed species. The infrared gas analyzer (IRGA), brand ADC, model LCA PROsd (Analytical Development Co. Ltd., Hoddesdon, UK) was set to work with environment parameters (no $\mathrm{CO}_{2}$ injection, natural light levels, reference air collected $4 \mathrm{~m}$ above soil surface in open air with no surrounding potential contaminants) to collect the data. Each block was evaluated in one day, between eight and nine o'clock in the morning, in order to maintain homogeneous environmental conditions during the analysis of each experimental block. In each day, plots into the block were randomly assessed.

Ninety DAP the following biometric variables were assessed: plant height $(\mathrm{cm})$ with graduated ruler from the soil surface to the apical meristem, stem diameter $(\mathrm{mm})$ determined with digital caliper $5 \mathrm{~cm}$ above soil surface, and leaf area $\left(\mathrm{cm}^{2}\right.$ plot $\left.^{-1}\right)$ with portable leaf meter model CI-203 (BioScience Inc., Washington, USA).

At 100 DAP, plants were cut at soil level, packed in paper bags and dried into forced circulation oven at $65 \pm 5{ }^{\circ} \mathrm{C}$ for four days to determine the dry shoot biomass $\left(\mathrm{g}\right.$ plot $\left.{ }^{-1}\right)$.

Data were subjected to ANOVA by the F-test at 5\% probability, and in being significant, $1^{\text {st }}$ degree linear regressions were applied to the quantitative factor (weed density). Regressions into the same graph were 
compared by the Relative Standard Deviation (RSD), according to Steel and Torrie (1980). All analysis was performed into the statistical environment "R" (R Core Team, 2017).

\section{Results and Discussion}

In general, most physiological parameters were not significant as function of the increasing in population density for all weed species. The biometric variables, however, were mostly affected by plant density (Figures 1 and 2). Furthermore, remarkable differences between weed species regarding the physiological traits were reported (Figure 2).
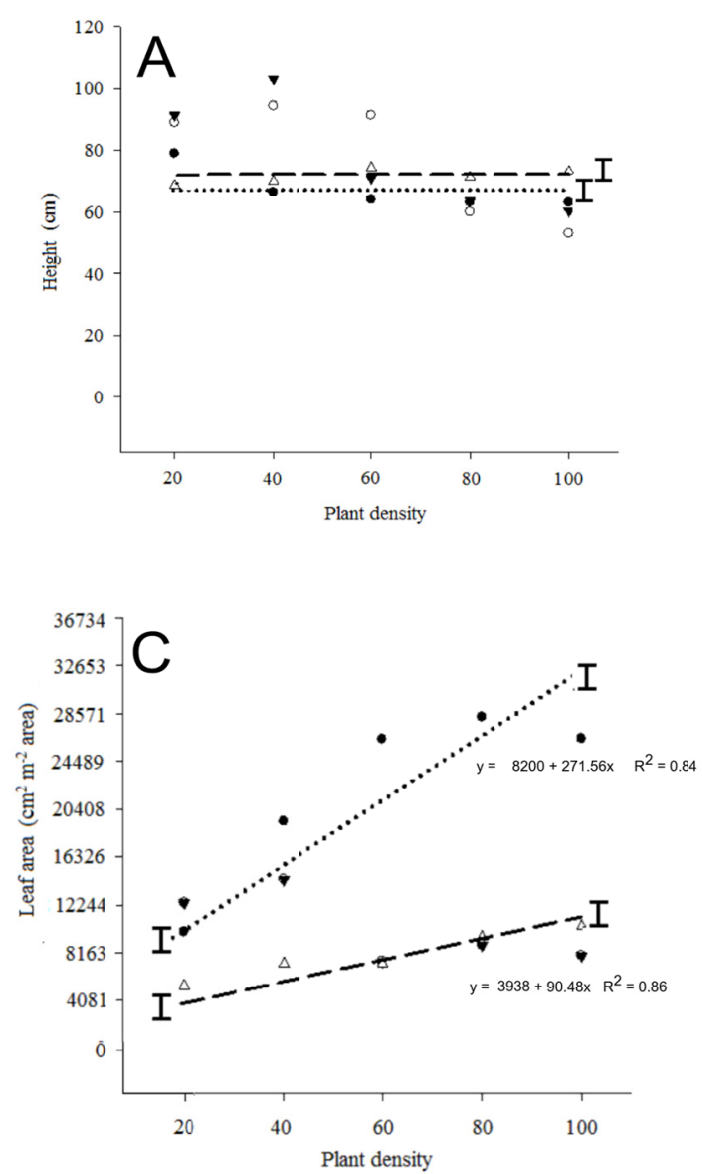
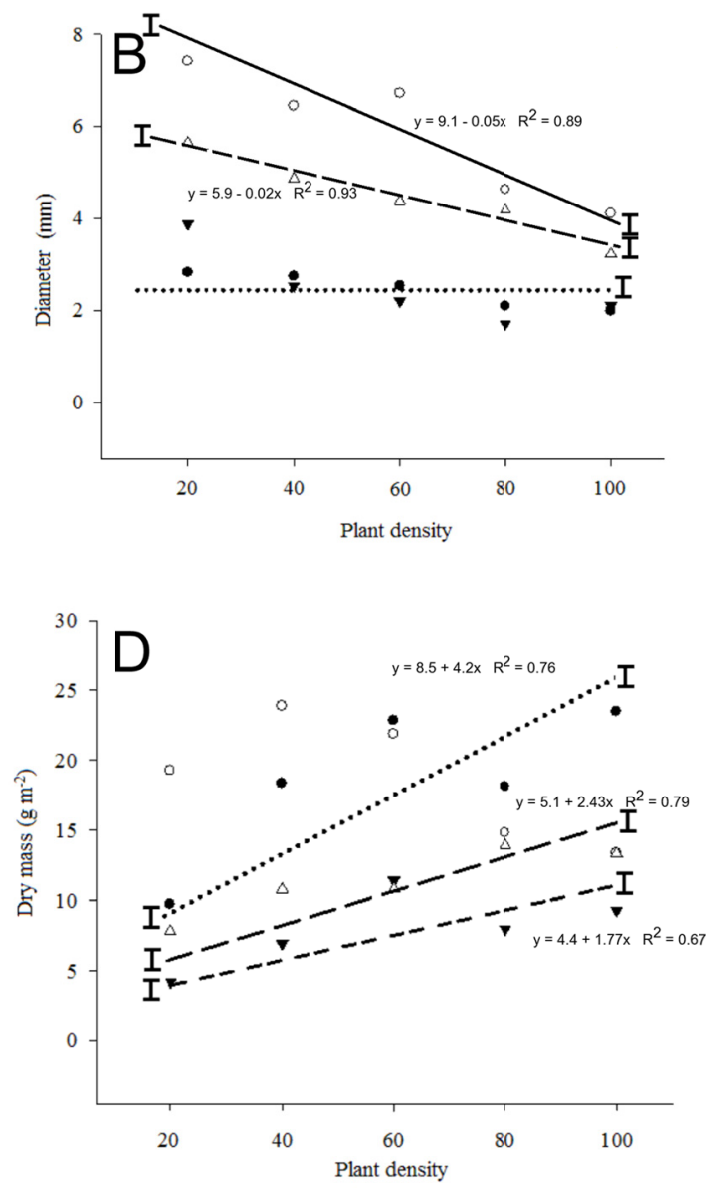

Figure 1. Plant height (cm) (A), stem diameter (B), leaf area (C) and shoot dry mass (D) of Alexandergrass (•), hairy beggarticks $(\circ)$, morning glory $(\boldsymbol{\nabla})$ and hairy fleabane $(\Delta)$ as a function of plant density

Plant height (Figure 1A) varied from 60 to $100 \mathrm{~cm}$ for all species, being considered similar by the F-test at 5\% probability. Plant height is an important trait from the competitive point-of-view, since taller plants usually stand out competition most efficiently than prostrate plant species, due to a better capture of radiation. Some authors consider the competition for light as important when it is present concomitantly with competition for water and nutrients; however, the interaction among these factors should be considered (Silva, A. Ferreira, R. Ferreira, \& Santos, 2007). Light cannot be stored into the system, thus the competition for this factor is considered as the capture for an instantaneous resource, being connected not only to the absorption features but also to its use efficiency (Bastiaans \& Kropff, 2017).

Stem diameter, differently from plant height, differed among species, where hairy beggarticks was the one with the strongest stem in lower plant densities, followed by hairy fleabane (Figure 2B). Alexandergrass and morning glory presented small stem diameter; the first one for being a poaceae plant where culms replace stems (Galon et al., 2014), and the second one for being a climbing plant species (Brighenti \& Oliveira, 2011).

The leaf area of these weeds (Figure 1C) differed greatly among species, being Alexandergrass the one with the highest maximum leaf area, reaching approximately $32000 \mathrm{~cm}^{2}$ of leaf area per $\mathrm{m}^{2}$ of soil. The other species 
accumulated between 4000 and $11000 \mathrm{~cm}^{2}$ of leaf area per $\mathrm{m}^{2}$ of soil (Figure 1C). Only Alexandergrass and fleabane leaf areas were affected by plant density. Plants tend to grow more in height to reach better positioning to capture the solar radiation, but this factor must be associated to a greater leaf area so that higher levels of active radiation are intercepted. However, the reduction in biomass and leaf area as plants grow taller may occur in compensation (Aspiazú, Concenço, Galon, Ferreira, \& Silva, 2008; Silva et al., 2009).
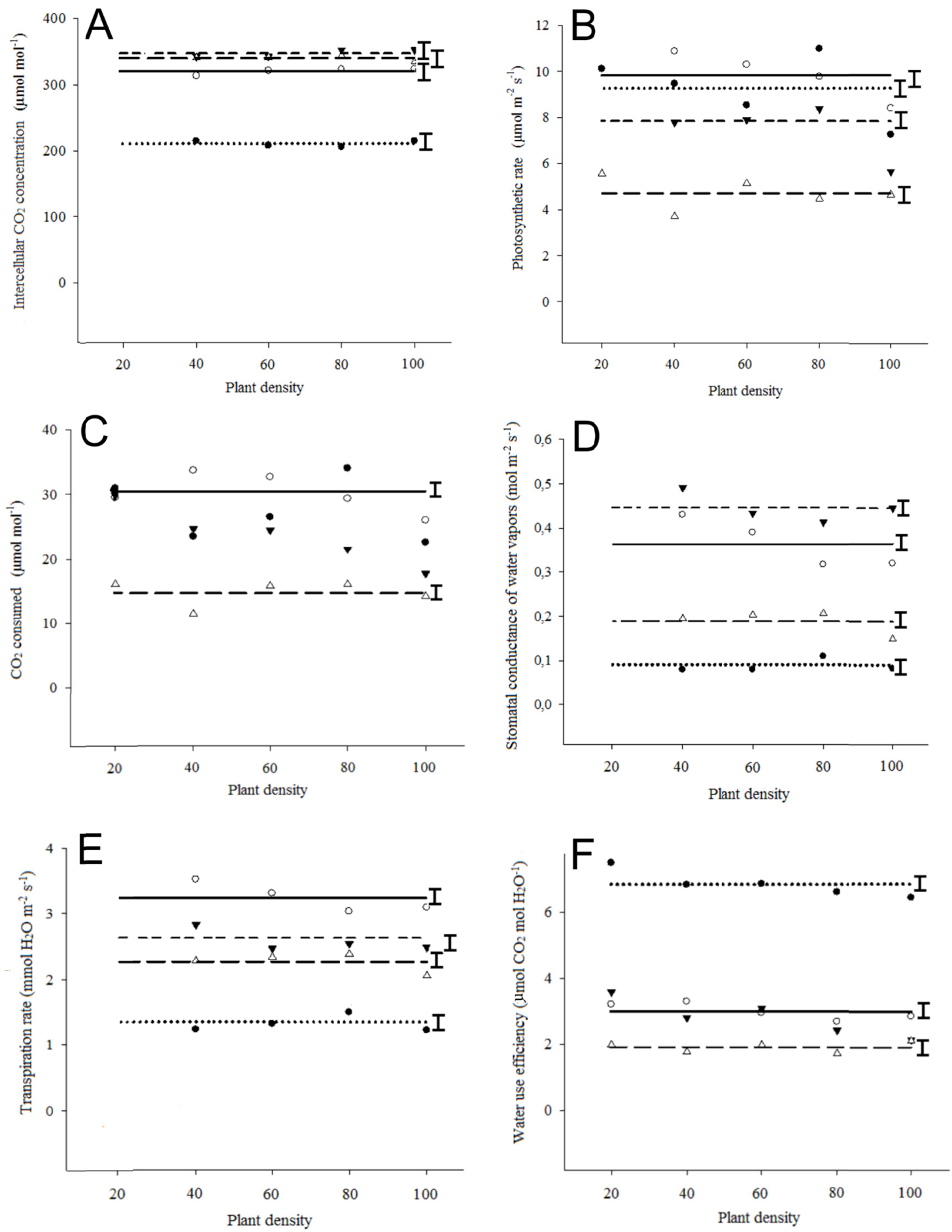

Figure 2. Sub-stomatic $\mathrm{CO}_{2}$ concentration $\left(C i-\mu \mathrm{mol} \mathrm{mol}{ }^{-1}\right)(\mathrm{A})$, photosynthetic rate $\left(A-\mu \mathrm{mol} \mathrm{m} \mathrm{m}^{-2}\right)(\mathrm{B}), \mathrm{CO}_{2}$ consumed $\left(\Delta C-\mu \mathrm{mol} \mathrm{mol}{ }^{-1}\right)(\mathrm{C})$, stomatal conductance of water vapors $\left(G s-\mathrm{mol} \mathrm{m}^{-2} \mathrm{~s}^{-1}\right)(\mathrm{D})$, transpiration rate $\left(E\right.$-mmol H$\left.{ }_{2} \mathrm{O} \mathrm{m}^{-2} \mathrm{~s}^{-1}\right)(\mathrm{E})$, water use efficiency $\left(E U A-\mu \mathrm{mol} \mathrm{CO} \mathrm{COl} \mathrm{H}_{2} \mathrm{O}^{-1}\right)(\mathrm{F})$, of Alexandergrass $(\bullet)$, hairy beggarticks $(\circ)$, morning glory $(\boldsymbol{\nabla})$ and hairy fleabane $(\Delta)$ as a function of plant density 
Weed dry mass (Figure 1D) differed greatly among species; hairy beggarticks, morning glory and hairy fleabane dry mass accumulation depended on plant density, where a higher number of plants into the area resulted in a proportional increased dry mass accumulation. This is a probable indicator that the competitive ability of these species may be centered on Density, one of the most notable phytosociological parameters in plant community dynamics (Concenço, Andres, Teló, Martins, \& Moisinho, 2017). Alexandergrass, on the other side, seems to center its competitive ability most probably on dominance (Galon et al., 2014) since its dry mass per area was high from low plant densities onwards.

In the physiological parameters, the concentration of intercellular $\mathrm{CO}_{2}(\mathrm{Ci})$ did not differ with increase in density, and it was observed from 310-350 $\mu \mathrm{mol} \mathrm{CO} \mathrm{Cmol}^{-1}$ for hairy fleabane, morningglory and hairy beggarticks and about $205 \mu \mathrm{mol} \mathrm{CO} \mathrm{mol}^{-1}$ for Alexandergrass (Figure 2A). Similarly, photosynthesis rate $(A)$ was not influenced by changes in plant density, and it was reported $9.5 \mu \mathrm{mol} \mathrm{CO} \mathrm{CO}^{-2} \mathrm{~s}^{-1}$ for hairy beggarticks and Alexandergrass, 7.9 $\mu \mathrm{mol} \mathrm{CO} 2 \mathrm{~m}^{-2} \mathrm{~s}^{-1}$ for morningglory and $4.6 \mu \mathrm{mol} \mathrm{CO} \mathrm{CO}_{2}^{-2} \mathrm{~s}^{-1}$ for hairy fleabane (Figure 2B). For consumed $\mathrm{CO}_{2}$, alexandergrass presented high $\mathrm{CO}_{2}$ consumption compared to hairy fleabane, with about $31 \mu \mathrm{mol} \mathrm{CO}_{2} \mathrm{~mol}^{-1}$ and $14 \mu \mathrm{mol} \mathrm{mol}^{-1}$, respectively, while hairy fleabane and morning glory did not differ statistically (Figure 2B).

The photosynthetic rate is the factor that indicates the progress in incorporation of carbon molecules into biomass. It is common to expect $\mathrm{C}_{4}$ plants to be more efficient than $\mathrm{C}_{3}$ plants; however, this occurs under certain conditions (Silva et al., 2007). In this case, the similar results between Alexandergrass $\left(\mathrm{C}_{4}\right.$ metabolism) and hairy beggarticks $\left(\mathrm{C}_{3}\right.$ metabolism) can be explained by the competitive strategy adopted by the latter. Hairy beggarticks is highly efficient in the absorption of water from soil, being able to develop adequately in soil water stress levels in which other species would already be undergoing moderate stress. This species removes water from the soil releasing it to the environment through luxury transpiration (Procópio, Santos, Silva, Martinez, \& Werlang, 2004a), until the species with which it competes undergoes water stress; from this point on, hairy beggarticks initiates stomatal opening control, managing water more adequately for its survival. Thus, hairy beggarticks may even be benefited by the occurrence of some water deficit (Procópio et al., 2004b; Silva et al., 2007), because it maintains the water potential gradient for water absorption, while other plants already activate signaling pathways for stomatal closure.

According to Concenço et al. (2012), $\mathrm{CO}_{2}$ consumption increases the difference in the concentration of this gas between the inside and outside of the leaf and, in general terms, the higher the gradient, the faster the $\mathrm{CO}_{2}$ entry into the leaf during periods of stomatal opening. Therefore, it is also possible to observe that lower $C i$ also results in a greater concentration difference $(\Delta C)$ between the mesophyll and the air of the surrounding layer of the leaf surface.

The water conductance differed among the four weed species, being $0.46,0.37,0.18$, and $0.9 \mathrm{~mol} \mathrm{H}_{2} \mathrm{O} \mathrm{m}^{-2} \mathrm{~s}^{-1}$ for morningglory, hairy beggarticks, hairy fleabane and alexandergrass, respectively (Figure 2D). Transpiration rates also varied among species, presenting 3.2, 2.7, 2.3, and $1.4 \mathrm{mmol} \mathrm{H}_{2} \mathrm{O} \mathrm{m}^{-2} \mathrm{~s}^{-1}$ for hairy beggarticks, morningglory, hairy fleabane, and Alexandergrass, respectively (Figure 2E). The water use efficiency (WUE), was remarkably superior for Alexandergrass, which presented rates above $6,0 \mu \mathrm{mol} \mathrm{CO} \mathrm{Col} \mathrm{H}_{2} \mathrm{O}^{-1}$; for hairy beggarticks and hairy fleabane this rate was 2.6 and $2.0 \mathrm{~mol} \mathrm{CO}_{2} \mu \mathrm{mol} \mathrm{H}_{2} \mathrm{O}^{-1}$, respectively (Figure $2 \mathrm{~F}$ ).

The WUE is calculated by the ratio between photosynthetic and transpiration rates, describing the close relationship between the rate of $\mathrm{CO}_{2}$ incorporation into biomass and the amount of water lost in the same time interval. The most efficient use of water is directly related to the photosynthetic efficiency as well as to the dynamics of the stomatal opening, because while plant absorb $\mathrm{CO}_{2}$ for photosynthesis, it loses water by transpiration at rates that depend on the difference of the potential gradient $(\Delta C)$ between the inner and the outer parts of the leaf (Floss, 2008), and the consequent differential stomatal conductance.

The most efficient use of water by Alexandergrass is associated to the fact that this species has $\mathrm{C}_{4}$ carbon metabolism, which has a higher affinity for $\mathrm{CO}_{2}$ due to the activity of the enzyme PEPcase when compared to a $\mathrm{C}_{3}$ plant, where Rubisco acts directly in the $\mathrm{CO}_{2}$ capture. Therefore, $\mathrm{C}_{4}$ species fix more $\mathrm{CO}_{2}$ per unit of water lost (Gurevitch, Scheiner and Fox, 2009). Considering energy demand, $\mathrm{C}_{4}$ plants are less efficient compared to $\mathrm{C}_{3}$ plants, since the fixed $\mathrm{CO}_{2} / \mathrm{ATP} / \mathrm{NADPH}$ ratio is 1:5:2 and 1:3:2, respectively. $\mathrm{C}_{4}$ plants have two carboxylation pathways, which require more energy for photosynthesis. This energy is obtained through solar radiation, so if access to light is limited, $\mathrm{C}_{4}$ plants will be less competitive than $\mathrm{C}_{3}$ species (Concenço et al., 2012), provided that other environmental conditions are reasonable for both species.

The WUE is important for weed survival and aggressiveness, but this isolated ability does not guarantee the good establishment of Alexandergrass, so that other factors such as $\mathrm{Ci}$ and $\mathrm{Gs}$, which describe the $\mathrm{CO}_{2}$ concentration in the leaf mesophyll and the flow rate of water vapor or $\mathrm{CO}_{2}$ through the stomata, may also be preponderant. Stomatal conductance is proportional to the size and number of stomata, and the intercellular carbon concentration 
is influenced according to the plant carbon metabolism, $\mathrm{C}_{3}$ or $\mathrm{C}_{4}$. Thus, the $\mathrm{CO}_{2}$ concentration can vary within a given community as a function of the time of day and be limiting to the photosynthesis under competitive conditions (Silva et al., 2007).

Alexandergrass presented better stomatal control ability to avoid water loss and at the same time high efficiency in the use of the available $\mathrm{CO}_{2}$, being able to maintain high photosynthetic rates even with greater periods of stomatal closure, which results in higher WUE (Aspiazú et al., 2010). The mechanisms of stomatal opening and closure depend on factors such as solar radiation, $\mathrm{CO}_{2}$ level in the mesophyll, relative air humidity, water potential, wind speed and growth substances inherent to each species (Galon et al., 2014), as well as others secondary factors.

\section{Conclusions}

The weed species studied present distinct competitive strategies aiming survival. Alexandergrass relies on high leaf area and growth rates, with superior control of stomatal opening and high water use efficiency. Hairy beggarticks efficiency in competition lies on its ability to remove water from soil (low water use efficiency on purpose) to levels when the other surrounding plant species would undergo stress, and then hairy beggarticks seems to optimize its stomatal control, managing the water stress while keeping adequate photosynthetic rates. Morning glory and hairy fleabane did not present detectable particular features in the study that could confer them superior competitive ability, and their importance as weeds is probably tied to other survival abilities but superior competition. In conclusion, the weed species studied present distinct competitive strategies.

\section{References}

Aspiazú, I., Concenço, G., Galon, L., Ferreira, E. A., \& Silva, A. F. (2008). Relação colmos/folhas de biótipos de capim-arroz em condição de competição. Revista Trópica, 2(1), 22-30.

Aspiazú, I., Sediyama, T., Ribeiro Jr., J. I., Silva, A. A., Concenço, G., Ferreira, E. A., ... Araujo, W. F. (2010a). Water use efficiency of cassava plants under competition conditions. Planta Daninha, 28(4), 699-703. https://doi.org/10.1590/S0100-83582010000400001

Bastiaans, L., \& Kropff, M. J. (2017). Weed competition. Encyclopedia of Applied Plant Sciences, 3, 473-478. https://doi.org/10.1016/B978-0-12-394807-6.00027-7

Brighenti, A. M., \& Oliveira, M. F. (2017). Biologia de Plantas Daninhas. In R. S. Oliveira Jr., J. Constantin, \& M. H. Inoue (Eds.), Biologia e Manejo de Plantas Daninhas. Curitiba, PR: Omnipax.

Concenço, G., \& Concenço, S. E. (2016). Conyza spp.: From Ugly Duckling to Agriculture's Fittest Swan-Brief Review. Planta Daninha, 34(1), 183-189. https://doi.org/10.1590/S0100-83582016340100019

Concenço, G., Andres, A., Teló, G. M., Martins, M. B., \& Moisinho, I. S. (2017). Phytosociological characterization of weeds as a function of residual herbicides applied to rice grown under sprinkler irrigation. Experimental Agriculture, 53, 1-12. https://doi.org/10.1017/S0014479717000059

Concenço, G., Aspiazu, I., Ferreira, E. A., Galon, L., \& Silva, A. F. (2012). Physiology of Crops and Weeds under Biotic and Abiotic Stresses. In M. M. Najafpour (Ed.), Applied Photosynthesis (pp. 257-280). Intech, Rijeka. https://doi.org/10.5772/30691

Floss, E. L. (2008). Fisiologia das Plantas Cultivadas (4th ed.). Passo Fundo, Brazil: Universidade de Passo Fundo.

Galon, L., Guimarães, S., Lima, A. M., Radunz, A. L., Beutler, A. N., Burg, G. M., ... Radunz, L. L. (2014). Interação competitiva de genótipos de arroz e papuã. Planta Daninha, 32(3), 533-542. https://doi.org/ $10.1590 / \mathrm{S} 0100-83582014000300009$

Gurevitch, J., Scheiner, S. M., \& Fox, G. A. (2009). Ecologia Vegetal (2nd ed.). Porto Alegre, Brazil: Artmed.

Procópio, S. O., Santos, J. B., Silva, A. A., Donagemma, G. K., \& Mendonça, E. S. V. (2004b). Ponto de murcha permanente de soja, feijão e plantas daninhas. Planta Daninha, 22(1), 35-41. https://doi.org/10.1590/ S0100-83582004000100005

Procópio, S. O., Santos, J. B., Silva, A. A., Martinez, C. A., \& Werlang, R. C. (2004a). Características fisiológicas das culturas de soja e feijão e de três espécies de plantas daninhas. Planta Daninha, 22(2), 211-216. https://doi.org/10.1590/S0100-83582004000200006

R Core Team. (2017). R: A language and environment for statistical computing. Vienna, Austria: R Foundation for Statistical Computing. Retrieved from http://www.R-project.org 
Radosevich, S., Holt, J., \& Ghersa, C. W. (1997). Physiological aspects of competition. Weed ecology: Implications for management (Vol. 6, pp. 217-301). New York: John Willey.

Sardana, V., Mahajan, G., Jabran, K., \& Chauhan, B. S. (2017). Role of competition in managing weeds: an introduction to the special issue. Crop Prot., 95, 1-7. https://doi.org/10.1016/j.cropro.2016.09.011

Silva, A. A., Ferreira, F. A., Ferreira, L. R., \& Santos, J. B. (2007). Biologia de plantas daninhas. In A. A. Silva, \& J. F. Silva (Eds.), Tópicos em Manejo de Plantas Daninhas (pp. 17-61). Viçosa, Brazil: Universidade Federal de Viçosa.

Silva, A. F., Concenço, G., Aspiazú, I., Ferreira, E. A., Galon, L., Coelho, A. T. C. P., ... Ferreira, F. A. (2009). Interferência de plantas daninhas em diferentes densidades no crescimento da soja. Planta Daninha, 27(1), 75-84. https://doi.org/10.1590/S0100-83582009000100011

Steel, R. G. D., \& Torrie, J. H. (1980). Principles and procedures in statistics: A biometrical approach (p. 633). New York: McGraw-Hill.

Vasconselos, M. C. C., Silva, A. F. A., \& Lima, R. S. (2012). Interferência de plantas daninhas sobre plantas cultivadas. Revista Agropecuária Cientifica no Semi Árido, 8, 1-6.

\section{Copyrights}

Copyright for this article is retained by the author(s), with first publication rights granted to the journal.

This is an open-access article distributed under the terms and conditions of the Creative Commons Attribution license (http://creativecommons.org/licenses/by/4.0/). 